\title{
Did sea-level change cause the switch from fissure-type to cen- tral-type volcanism at Mount Etna, Sicily?
} Sustainable Earth Institute, School of Geography, Earth \& Environmental Sciences, University of Plymouth, Plymouth, PL4 8AA, UK;
*Corresponding author, E-mail: istewart@plymouth.ac.uk

(Received: March 3, 2017; Revised accepted: September 20, 2017)

http://dx.doi.org/10.18814/epiiugs/2018/v41i1/018002

One of the most intriguing aspects of the evolution of Mount Etna (eastern Sicily) is the switch from a fissuretype shield volcano coincident with the Ionian coast to an inland cluster of nested stratovolcanoes close to the currently active centre. Previous geological studies infer that the switch reflects a tectonically-driven rearrangement of the major border faults that direct the Etnean plumbing system, loosely dated at around $125 \mathrm{ka} \mathrm{BP}$. New offshore structural studies throw this prevailing view into question, whilst a revised chronological framework indicates that the transformation from fissure- to central-type activity was abrupt, effectively occurring 129-126 ka BP. In recognising that this period corresponds closely with the Eemian sea-level highstand (Marine Isotope Stage 5e; 124-119 ka $B P)$, the paper examines whether eustatic fluctuations may have triggered the fundamental change in Mount Etna's magmatic behaviour, and suggests that a similar tendency may affect other volcanic centres in the region.

\section{Introduction}

One of the most intriguing aspects of the evolution of Mount Etna is its switch from a fissure-type shield volcano along the present Ionian coast to a cluster of nested stratovolcanoes adjacent to the currently active summit of the modern edifice. Although this switch has long been recognised as the single most important transformation in the volcano's history (Rittman, 1973) no studies have addressed it directly, in part because its timing was loosely constrained. A recent ${ }^{40} \mathrm{Ar} /{ }^{39} \mathrm{Ar}$ radiometric chronology (De Beni et al., 2005) has established tighter constraints on the magmatic history (Branca et al., 2007: De Beni et al., 2011), which coupled with an improved understanding of the structural framework of the Etnean edifice, make it timely to reassess prevailing views on the origin of Europe's largest volcano.

Mount Etna's eruptive history began 500 ka BP ago with submarine volcanism (named the Basal Tholeiitic (BT) eruptive phase), but about 220 ka ago sustained fissure-type eruptive activity built a N-S chain of subaerial eruptive centres strung out along present-day coast (Gillot et al., 1994) (Figs. 1 and 2). Almost continuous effusion of magma constructed a broad shield volcano immediately east of Etna's coastline (Fig. 2), manifest as an elongated topographic ridge approximately a hundred metres or so high - along the Timpe fault belt (Corsaro et al., 2002). In the south, effusive outpourings of the 'Timpe Volcano' ended $142 \mathrm{ka}$ BP with the emplacement of the Uppermost Lava Unit (Gillot et al., 1994; De Beni et al., 2005); above this, the succession is capped by fossiliferous tuffites, indicating that lava production ceased as the southern end of the volcanic ridge became submerged beneath shallow marine waters (Corsaro et al., 2002) (Fig. 2). The more elevated northern sector of the Timpe volcano, however, remained above sea level and continued to build, with eruptive activity ending here about $130 \mathrm{ka}$ BP (De Beni et al., 2005). After this time, the Timpe 'line' ended as an eruptive axis but continued as an active fault zone (Lo Giudice and Rasa, 1986; Azzaro, 1999) (Fig. 2).

With the cessation of fissure-type eruptions from the Timpe shield volcano, Etnean volcanism switched to the production of alkaline magmas from central-type edifices inboard of the coast. The earliest evidence for this is found at Moscarello, inland of the northern tip of the Timpe di Acireale (De Beni et al., 2005; Branca et al., 2007; De Beni and Gropelli, 2010), where a lava succession represents an intense burst of fissure-type activity emplaced between $129.9+/-2.4$ and $126+/-2.4 \mathrm{ka} \mathrm{BP}$ (Fig. 1). Further west, in the Val Calanna, a cataclastic lava yielded an age of $128.7+/-3.8 \mathrm{ka}$ BP. Later fissure-type eruption products also occur inland, notably the lava flow dated at $121.2+/-7.5 \mathrm{ka} \mathrm{BP}$ and associated with the Aci Catena strand of the Timpe fault system. The implication is that Timpe faults inboard of the original coastal eruptive axis had now taken over as preferential feeder zones.

The first evidence of true central-type (Valle del Bove-VdB) rather than fissure-type (Timpe) eruptive activity occur with the construction of the Rocche and Tarderia volcanic centres, which were located on a N-S axis and apparently coeval in age (Fig. 1) (Branca et al., 2007). The activity of the Rocche volcano - a small polygenetic centre located near the northeast wall of the Valle del Bove flank collapse amphitheatre - ended about 101.9 +/- 3.8 ka BP (De Beni et al., 2005). To the south, a lava flow attributed to the Tarderia volcano was dated at 105.8+/- 4.5 ka BP (Beni et al., 2005), indicating that it had ceased eruptive activity by $106 \mathrm{ka} \mathrm{BP}$ (Branca et al., 2007).

Thereafter, eruptive activity is dominated by major Plinian eruptions of Si-rich (benmoreite) magma from a source located further to the west in the Valle del Bove amphitheatre (Coltelli et al., 2000), with the earliest dated at $99.1 \pm 5.3 \mathrm{ka} \mathrm{BP}$ (Del Carlo et al., 2004) (Fig. 1). 


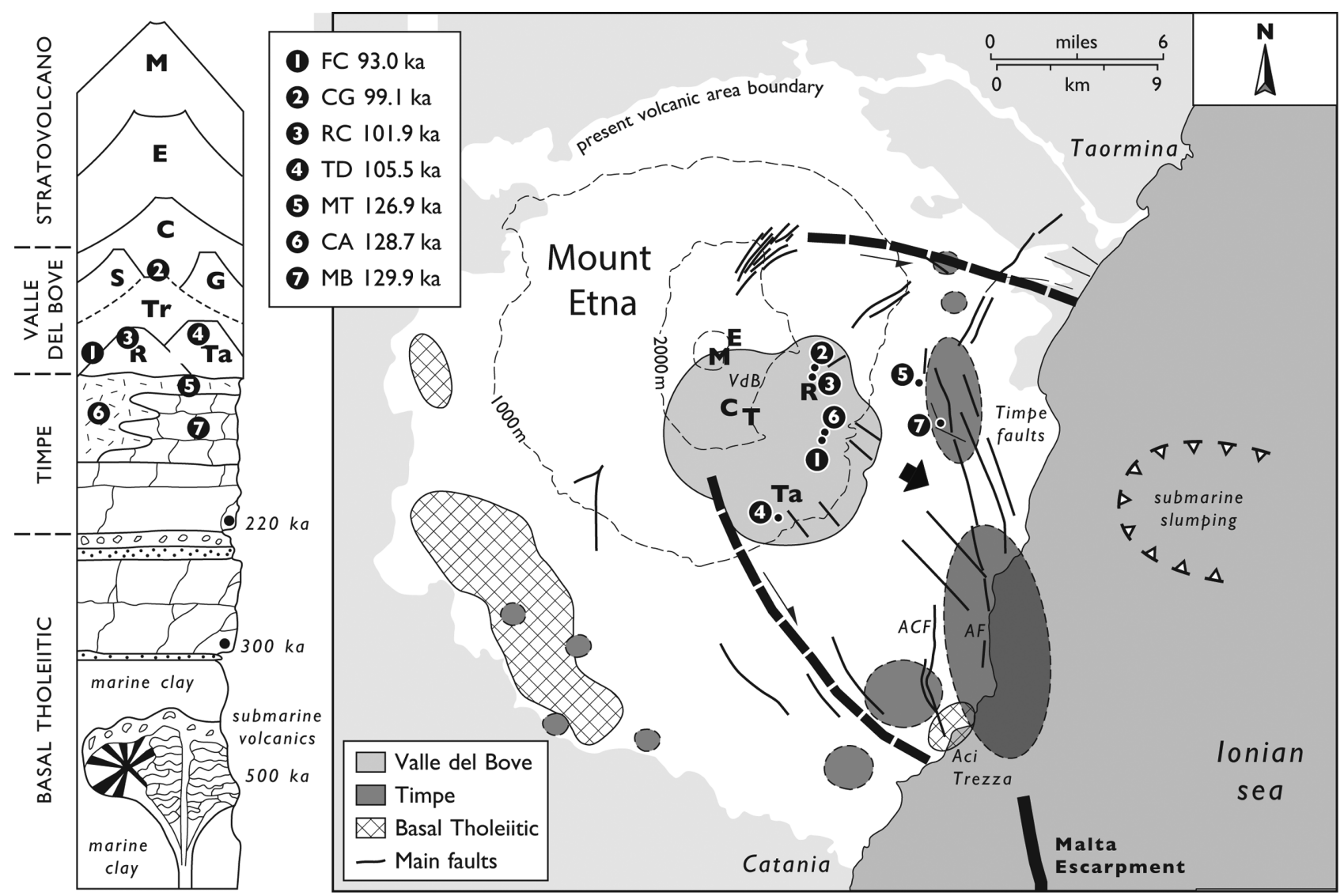

Figure 1. Location map of Mount Etna showing the distribution of the main central-type eruptive centres (from oldest: $R$, Rocche; Ta, Tarderia; T, Trifoglietto; G, Giannicola; S, Salifizio; C, Cuvigghiuni; E, Ellitico; and M, Mongibello), the fissure-type products of the preceding Timpe phase, and the earliest Etnean products of the Basal Tholeiitic phase (from De Beni and Groppelli, 2011, fig. 1). The map is integrated with the sample sites and the associated ages of ${ }^{40} A r{ }^{\beta^{9}}$ Ar radiometric dating determinations reported by De Beni et al. (2005) and Branca et al. (2007): MB, lave flow at base of the Moscarella Timpe; CA, cataclastic lava flow at the base of the Val Calanna; MT, lava flow at the top of the Moscarella Timpe; TD, lava flow from Tarderia centre; RC lava flow; CG, tephra layer of the Cava Grande litho-horizon; FC, lava flow in the Val Calanna. The volcanic context of the ${ }^{40} \mathrm{Ar} \mathrm{F}^{39}$ Ar dates are depicted in the accompanying schematc stratigraphic column (from De Beni and Groppelli, 2011, fig. 4). The limits of the seaward sliding sector of eastern Etna is delimited by a pair of thick dashed lines, along with the main tectonic structures of the volcano, including the Malta Escarpment [ME], and the system of 'Timpe' faults which cut the eastern flank (including the Acireale Fault [AF] and the Aci Catena Fault [ACF] referred to in the text). Vdb denotes the Valle del Bove collapse scar.

Around $80 \mathrm{ka} \mathrm{BP}$, however, there is a change in magma composition and eruptive style, involving the strombolian to subplinian eruption of basalt to mugearite compositions (Coltelli et al., 2000). From this time, central-type eruptions were concentrated in the southern sector of the Valle del Bove where the main eruptive centre of this phase the Trifoglietto volcano - grew and developed (Fig. 1). Three minor eruptive centres - Giannicola, Salifizio and Cuvigghiuni - subsequently formed on the flanks of Trifoglietto, remaining active until about $60 \mathrm{ka}$ BP when central-type volcanism shifted westward again to the present locus of Etnean activity.

The final and ongoing phase of eruptive activity - the Stratovolcano (SV) eruptive phase - began at $60 \mathrm{ka}$ with the permanent stabilization of the plumbing system in the Etna region and the consequent construction of the large Ellittico volcano which forms the bulk of the present edifice (Fig. 1) (Branco et al., 2007). The Ellittico stage ended about $15 \mathrm{ka} \mathrm{BP}$ with a series of powerful Plinian eruptions (Coltelli et al., 2000) that destroyed the summit of the volcano, leaving behind an elliptical caldera. Following filling of the caldera, the current (Mongi- bello) eruptive centre developed close to the site of the Ellittico centre. Over the last 14,000 years, Mongibello products have covered around 85 percent of the volcano (Branca et al., 2004).

A key conclusion of Mount Etna's new integrated chronostratigrahic framework is that '...since $129 \mathrm{ka}$ ago, a gradual westward shifting of the volcanic activity from the tip of the Timpe faults towards the Valle del Bove area, recorded by the Calanna, Moscarella, Tarderia and Rocche volcanics, marked the transition from fissure- to central-type eruptive activity' (Branca et al., 2007, p. 150) and that by '...120 ka a stabilization of the volcano feeder system occurred in the VdB area' (Branca et al., 2007, p. 136). This transition from the alkaline lavas of the coastal Timpe phase to a more evolved magma (benmoreite) in the centraltype eruptions implies increasing crystal fractionation of the magma, which in turn, is consistent with longer residence times at shallow depths. The implication is that the volcano underwent a fundamental reconfiguration of its plumbing system over the course of just a few millennia. 


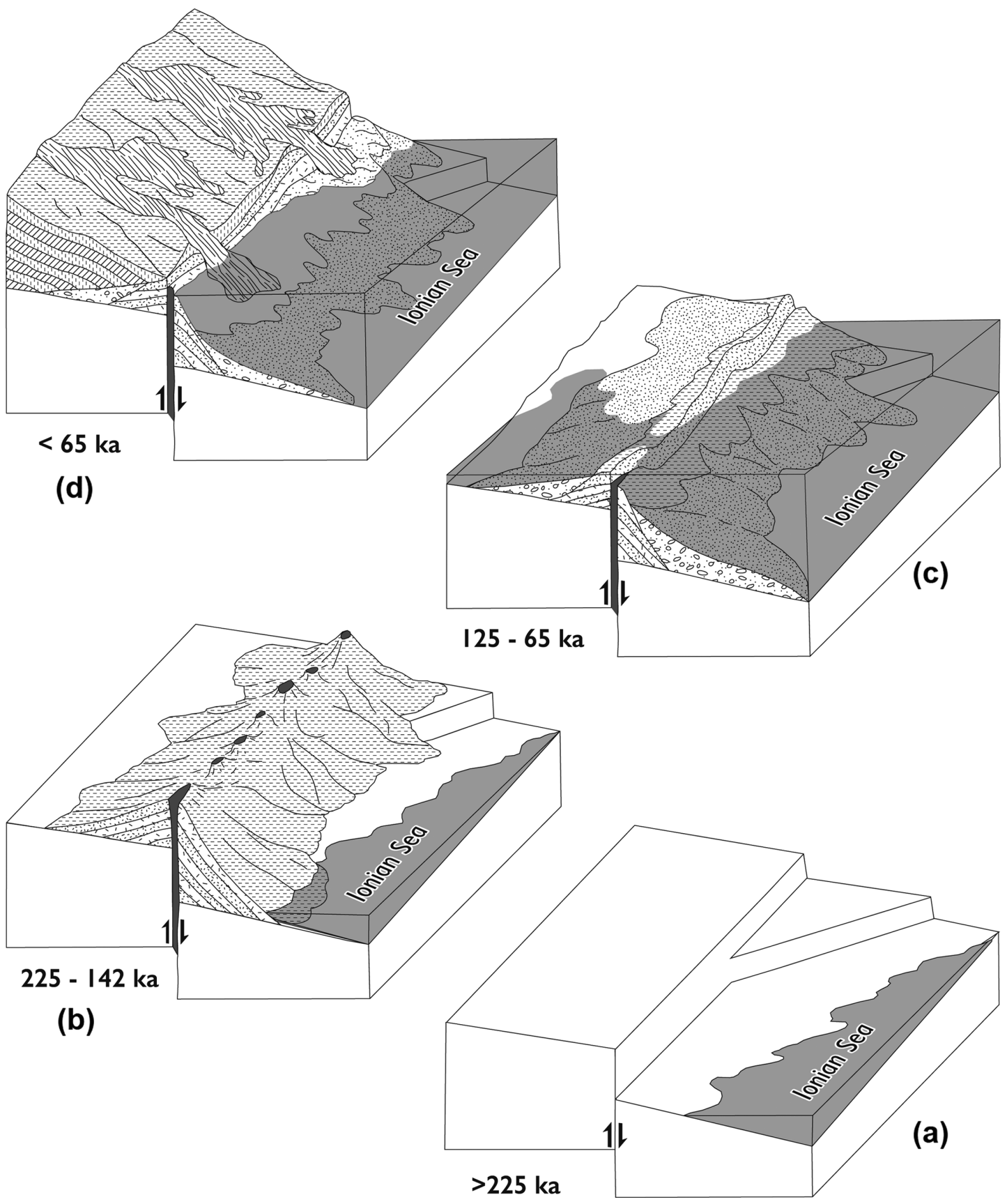

Figure 2. A schematic four-stage palaeoenvironmental reconstruction and volcano-tectonic evolution of the lower southeastern Etnean sector, redrawn from Corsaro et al. (2002, fig. 10). (a) From $225 \mathrm{ka}$ BP magma rises up the Timpe Fault at the northern end of the Malta Escarpment. (b) Between 225 and $142 \mathrm{ka}$ BP volcanic activity along a chain of fissure-type eruptive centres builds a ridge of lava cropping out along the present Timpe escarpment. (c) Between 142 and 125 ka volcanic activity ceases along the Timpe ridge, after which shallow marine depositional conditions prevail in the south and continental depositional conditions remain in the north. (d) After 65 ka BP, the area is buried by lava flows dipping eastward from edifices and eruptive fissures in the vicinity of the current stratovolcano, though these deposits are disrupted by a tectonically active Timpe Fault.

\section{A Tectonic Readjustment?}

Although no studies address directly the cause of this dramatic magmatic reconfiguration, those that mention it suggests that it reflects a local tectonic readjustment. Branca et al. (2007, p. 148) summarise it thus: 'Between about 129 and $126 \mathrm{ka}$, the volcanism concentrated on the northern tip of the fault system. In this time span, we observe the westward shifting of the main plumbing system due to the NW migration of the extensional regime of the Timpe fault system towards the central portion of the Etna edifice'. This interpretation builds on the contention of Catalano et al. (2004, p. 311) that '.... major change in the mode of deformation, since $125 \mathrm{ka} \mathrm{BP}$, was related to the propagation of a normal fault belt along the Ionian coast of the Catania region and the eastern sectors of the Etnean edifice.'

The evidence for this change in Etna's structural framework comes 
from studies of late Pleistocene marine terraces along Sicily's eastern shores. At Taormina, to the north east of the edifice, the post- $125 \mathrm{ka}$ BP marine surfaces infer an uplift rate of $1.4 \mathrm{~mm} / \mathrm{yr}$ but higher (older) terrace levels indicated a slower uplift rate of $0.8 \mathrm{~mm} / \mathrm{yr}$, thereby implying an acceleration in tectonic uplift (Monaco et al., 2002). In that terrace reconstruction, however, the $125 \mathrm{ka}$ (MIS 5.5) terrace was attributed to a prominent bench at a present-day elevation of $180 \mathrm{~m}$ (Catalano and Guidi, 2003; de Guidi et al., 2003), but a more recent radiometric (U-series) age of $124.5+/-15 \mathrm{k}$ for a terrace level at $+115 \mathrm{~m}$ at Taormina suggests that is the MIS 5.5 level (Antonioli et al., 2006). This age determination gives a revised post- $125 \mathrm{ka}$ BP uplift rate of $0.87 \mathrm{~mm} / \mathrm{yr}$ and hence implies no abrupt acceleration in the long-term uplift rate. Moreover, in the Etnean sector itself a staircase set of ancient marine terrace levels at Aci Trezza that are correlated with highstands going back to $200 \mathrm{ka}$ BP yield a roughly constant uplift rate of $1.35 \mathrm{~mm} / \mathrm{yr}$ across this period (Monaco, 1997; Monaco et al., 1997, 2002). In short, the late Pleistocene marine terrace record provides little or no support for a major geodynamic change along Mount Etna's coastal border fault.

Models of the geodynamics of Mount Etna's eastern flank have long been based on onshore structural data, which portray the volcanic edifice as being superimposed onto the uplifting footwall of a major normal fault system: the Malta Escarpment (Hirn et al., 1997; Monaco et al., 1997). In the last few years, however, high-resolution reflection seismic profiles immediately offshore of Mount Etna have shown no evidence of direct structural continuity between this long-lived, deepseated lithospheric tear and the onshore Timpe fault system (Nicolich et al., 2000; Argnani et al., 2005; Chiocci et al., 2011; Argnani et al., 2013; Gross et al., 2016). It is possible that the two are connected via soft-linkage across a westward, left-stepping ramp, but the fault morphology is very different (Argnani et al., 2013); the Timpe scarps define a distributed transtensive (normal slip with a minor right-lateral component) networks that lack the well-defined extensional basins which to the south characterize the classic half-graben geometries immediately offshore of the Hyblean Plateau (Argnani and Bonazzi, 2005). Instead, the seismic reflection datasets indicate the presence of a significant E-W trending transcurrent structure (Gross et al., 2016), possibly of regional significance (Polonia et al., 2016). What is clear is that the Timpe extensional sector is dominated by gravitational sliding of Etna's eastern flank (Gross et al., 2016), with GPS and seismic monitoring confirming that the Timpe faults are actively involved in a moving mosaic of tectonic blocks sliding seaward over a shallow decollement (Azzaro et al., 2013). Although implicated in active seaward sliding, the Timpe's link with magmatism and current seismicity, recorded down to $10 \mathrm{~km}$ or more, indicates that they are crustal-scale tectonic structures that root into the deeper plumbing system (Argnani and Bonazzi, 2005).

The picture emerging from the marine realm is of a high degree of structural complexity offshore of Mount Etna that obscures a simple and direct tectonic intervention into the magmatic evolution of the volcano. Although a late Pleistocene reorganization of Etna's local tectonic framework remains plausible, there is no evidence that it occurred at $125 \mathrm{ka}$ BP and no explanation why it should have been abrupt enough to trigger the millennial-scale transition from coastal fissure-type to inland central-type eruptive activity.

\section{A Correlation with Late Pleistocene Sea-level Change?}

An alternative frame within which to consider Etna's dramatic magmatic reorganization is that of late Pleistocene eustatic change, noting that the timing of the fissure- to central-type switch coincides with onset of the last interglacial (Eemian; MIS substage 5e) sea-level highstand between 126 and $119 \mathrm{ka} \mathrm{BP} \mathrm{(Spratt} \mathrm{and} \mathrm{Lisiecki,} \mathrm{2016)}$ (Fig. 3). A correlation between eustatic fluctuations and the timing of explosive volcanism has been established in the Mediterranean region (McGuire et al., 1997b) and it appears that it is the pace of eustatic change that is critical in modulating coastal volcanism, with Kutterolf et al. (2013) showing that increased volcanism globally lags a few millennia behind the fastest rates of sea-level rise.

In terms of the Eemian highstand, global sea levels began rising following deglaciation at $142 \mathrm{ka} \mathrm{BP}$ (Thomas et al., 2009), reaching present levels at $130 \mathrm{ka}$ BP (Stirling et al., 1998; Gallup et al., 2002; Peltier and Fairbanks, 2006; Kopp et al., 2009). Between 126-119 ka BP sea levels were up to $10 \mathrm{~m}$ higher than modern sea level (Kopp et al., 2009), though with significant short-lived eustatic oscillations (e.g., Thompson and Goldstein 2005; Rohling et al., 2008). After $115 \mathrm{ka}$ BP, sea levels dropped to 40-60 metres below the present day during the following stadial period (MIS 5d) which ended with a return to a temporary highstand around 105 ka BP (MIS 5c) (Lambeck et al., 2002). Interstadial conditions ended about $92 \mathrm{ka} B P$ when sea levels dropped during a stadial period before terminating in the interstadial highstand at $82 \mathrm{ka} \mathrm{BP}$ (MIS 5a) when sea levels were around $20 \mathrm{~m}$ below those of today (Lambeck et al., 2002; Cutler et al., 2003; Potter et al., 2004). From $77 \mathrm{ka}$ BP a transition to MIS4 stadial conditions was marked by a $40-60 \mathrm{~m}$ eustatic fall, with sea levels thereafter oscillating markedly every few millenia, before interstadial highstand conditions return at $57 \mathrm{ka} \mathrm{BP}$ (MIS 3) and then at 49-52, 44, 36 and $32 \mathrm{ka}$ BP (Lambeck et al., 2002; Cutler et al., 2003). The end of the MIS 3 interstadial occurs at $30 \mathrm{ka} \mathrm{BP}$ when sea levels plunged 30-40 metres within a few millenia as full glacial conditions took hold, marking the onset of the Last Glacial Maximum (LGM).

Viewing Mount Etna's volcanic history in the context of this global eustatic framework (Fig. 3), the following associations can be noted:

(1) The onset of deglaciation and sea-level rise at $142 \mathrm{ka}$ BP coincides with the cessation of the fissure eruptive history in the southern part of the Timpe shield volcano, a transgression that is ultimately marked by the marine (fossiliferous) tuffs that cap the final lava flows of the fissure ridge.

(2) With the establishment of full highstand conditions from $130 \mathrm{ka}$ $\mathrm{BP}$, eruptive activity switched away from the coast to eruptive axes inland.

(3) The onset of MIS $5 \mathrm{c}$ highstand at $105 \mathrm{ka}$ BP coincides with the termination of the eruptive centres of the Tarderia and Rocche and the beginning of Valle del Bove phase of volcanism.

(4) The MIS 5a highstand (82 ka BP) marks the initiation of the Trifoglietto volcanic phase with central-type Valle del Bove volcanism.

(5) The onset of MIS 3 highstand conditions at $57 \mathrm{ka}$ BP marks the westward move to the Ellitico eruptive centre where the great bulk of the present-day edifice is constructed. 


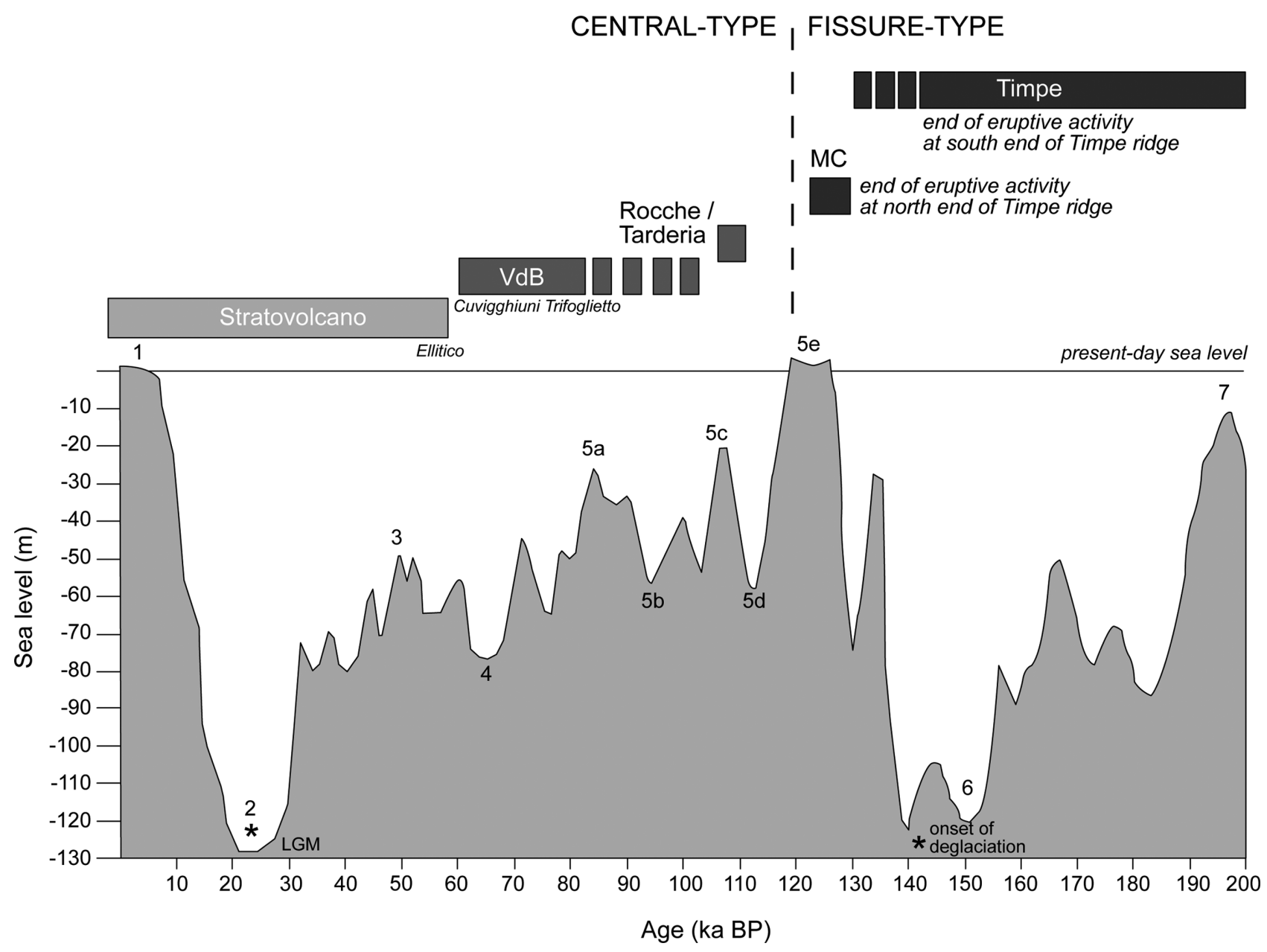

Figure 3. Correlation between late Pleistocene sea level changes and key episodes in Etnean volcanism highlighting the switchover from fissure-type to central-type magmatism at the time of the Eemian (125 ka BP) highstand. Numbers refer to marine isotope stages (MIS) and eustatic curve from Lambeck et al. (2002).

Late Pleistocene eustatic changes have been implicated in changes in the behavior of other coastal volcanoes, with episodes of catastrophic edifice collapse (e.g., McGuire, 1996; Manconi et al., 2009; Hunt et al., 2013; Ramalho et al., 2013) appearing to coincide with interglacial sea-level highstands (Quidelleur et al., 2008) (Fig. 4). A review by Coussens et al. (2016) contends that all the well-dated, large-scale collapse episodes on Montserrat in the Lesser Antilles Arc occurred during periods of rapid sea-level rise, and this coupling appears to be replicated within a global data set for island-arc volcanoes. The Eemian highstand appears to be especially prominent. In the Canary archipelago, El Hierro experienced the first of two major collapses at $134 \pm 6 \mathrm{ka}$ (Carracedo et al., 1999) and on nearby La Palma, Cumbre Vieja starts to grow at $125 \mathrm{ka}$ BP (Guillou et al., 1998). On Hawaii, the Mauna Loa volcano has a major collapse (Alika phase 2) at $127 \pm 5 \mathrm{ka}$ (McMurtry et al., 1999), whilst on Martinique Island (French West Indies), a flank collapse at $127 \pm 2 \mathrm{ka}$ destroyed the long-lived Mt Conil edifice (Germa, 2011). The volcanic history of Montserrat is especially telling, with consistent magmatic compositions since $2 \mathrm{Myr}$ interrupted by a rapid shift at $130 \mathrm{ka}$, when a large collapse of the andesitic-dominated Soufrière Hills Volcano led to the formation of a new basaltic volcanic center, the South Soufrière Hills (Cassidy et al., 2012, 2015). This large flank collapse at $130 \mathrm{ka}$ occurred at the end of peak explosive activity, with other periods of heightened eruptive activity coinciding with MIS transitions at 105, $75+/-10,50$ and $<12 \mathrm{ka}$. The correspondence led Wall-Palmer et al. (2014, p. 3017) to propose that ' .... a tentative correlation can be made between more vigorous activity on Montserrat and changes in global (eustatic) sea level and climate.'

There is also support for a general correspondence between magmatic changes and sea-level highstands associated with Marine Isotope Stage 5 (MIS 5e-125ka; MIS 5c-105 ka; MIS 5a-85 ka) closer to Mount Etna. Nearby, on the Aeolian archipelago, detailed chronostratigraphical studies (Lucchi et al., 2013) have established a complex interplay between volcanism, tectonic activity and sea-level fluctuations, which is summarized in Figure 5. Generally, along the SalinaLipari-Vulcano system an early phase of mafic to intermediate evolved magmas producing effusive, strombolian and lava fountain activity switches around the time of the Eemian highstands to a more recent higher energy eruptive phase involving rhyolitic melts or increased magma-water interaction, suggesting an abrupt shallowing of the magmatic systems of the central Aeolian sector (De Rosa et al., 2003). On Lipari, for example, early volcanism was characterized by fissuretype eruptions from at least $188 \mathrm{ka}$ BP but changed to central-type eruptions from aligned monogenic centres after $127 \mathrm{ka}$ BP (Lanzo et 


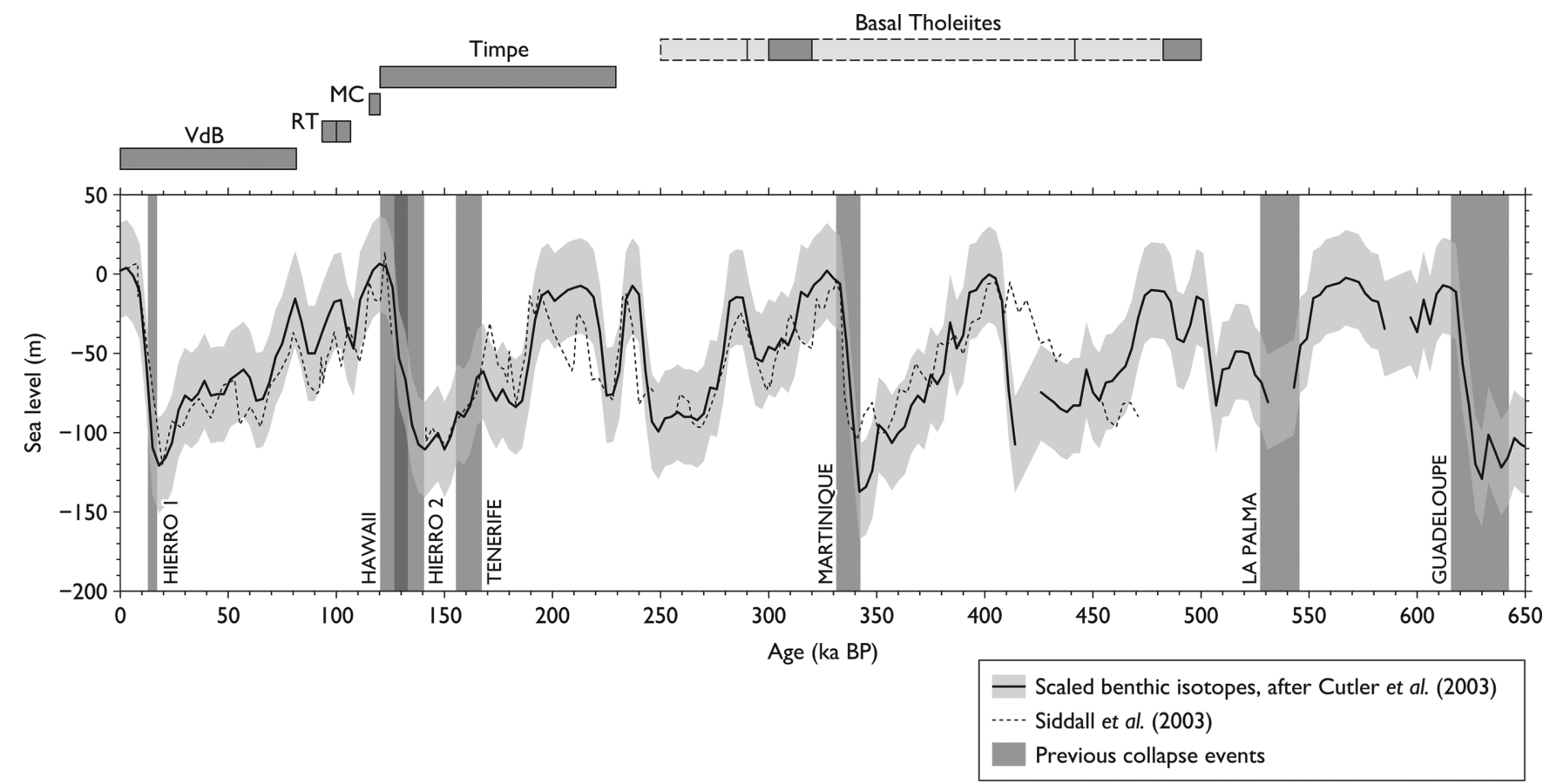

Figure 4. Major flank collapse at coastal and island volcanoes appear to coincide with interglacial sea-level highstands (redrawn from Quidelleur et al., 2008). The chronology of the Etnean eruptive history is shown above.

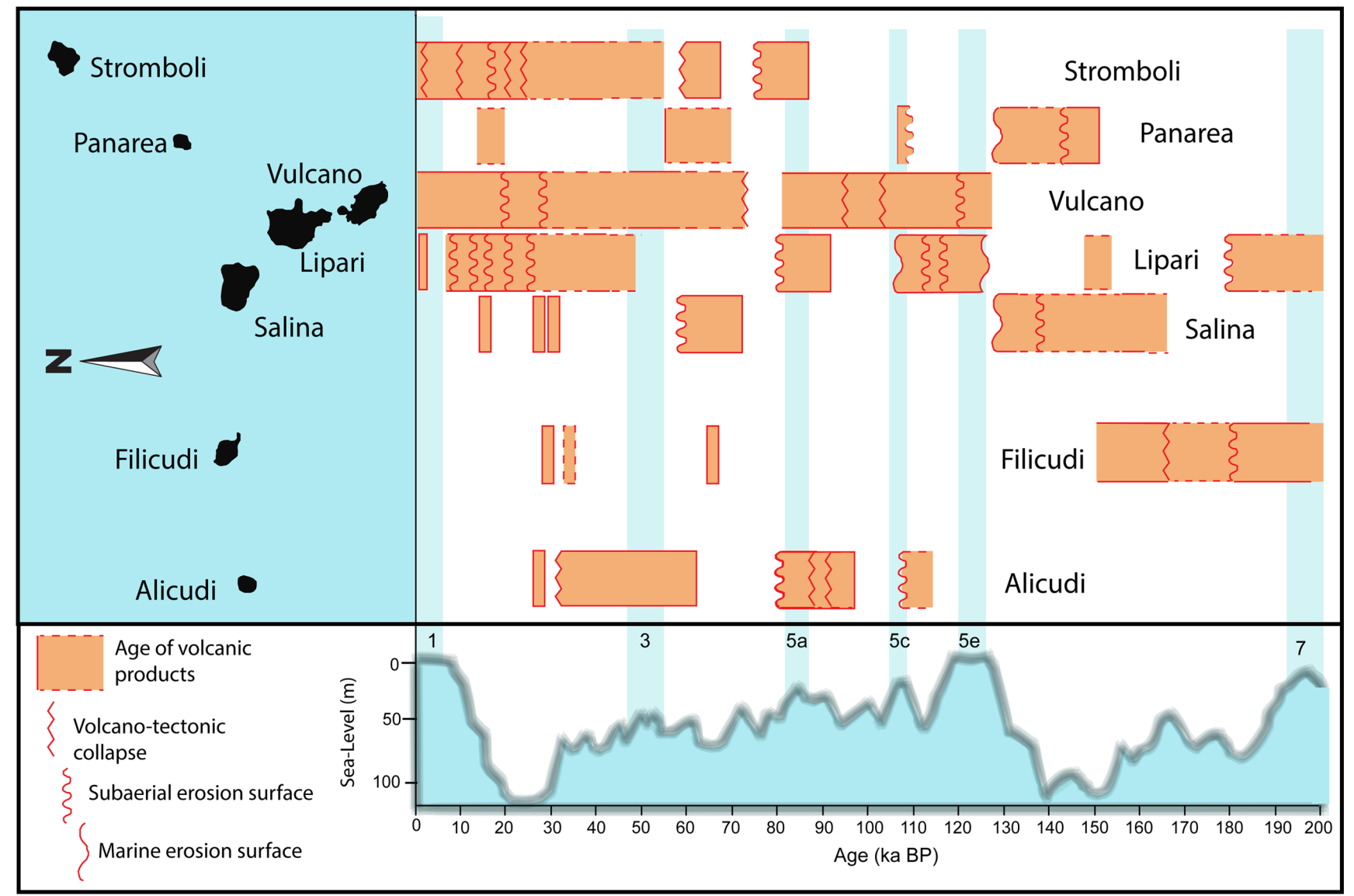

Figure 5. Schematic diagram showing chronostratigraphical relations between volcanic activity and late Pleistocene sea-level change across the Aeolian archipelago of Southern Italy. The main phases of eruptive activity on each of the volcanic islands are from Lucchi (2013, fig. 5.1). Lightly shaded vertical bars mark the timing of the principal sea-level highstands, shown below in the eustatic sea-level curve (simplified from Lambeck et al., 2002). 
al., 2010), when two main stratovolcanoes developed in the central part of the island (Ruch et al., 2016). On Vulcano, at least three basaltic lava cones built up the Primordial Vulcano during the period 135 to $100 \mathrm{ka}$ ago, before the collapse of Piano caldera occurred at $99.5 \mathrm{ka}$ (Ruch et al., 2016). Finally, at Salina, fissure-type eruptions controlled by regional faults dominate from 244 to $226 \mathrm{ka}$, after which a long quiescence allowed volcanic activity to migrate to the south west, restarting around $160-168 \mathrm{ka}$ as a pair of volcanic centres rooting into a shared plumbing system still controlled by regional tectonics (Nicotra et al., 2014). According to these authors, the final transition from fissure-type to central style eruptions at Salina occurred soon after $131 \mathrm{ka}$ (Leocat, 2010), before central-type eruptive activity fed by shallow magma storage was fully established from $87 \mathrm{ka}$. The onset of that final eruptive phase at Salina, which is contemporaneous with the commencement of edifice growth at Stromboli (Francalanci et al., 2013), is argued to represent the cessation of the regional tectonic influence on magmatism across the archipelago (Nicotra et al., 2014).

To the south of Etna, at Pantelleria volcano in the Straits of Sicily, major tephra layers offshore are dated at 127.5, 128.1, and $129.1 \mathrm{ka}$ BP (Tamburrino et al., 2012), major ignimbrite eruptions onshore are dated at $123 \pm 1.6$ and $107 \pm 0 \mathrm{ka}$ (Mahood and Hildreth, 1986) and a welded breccia deposit correlated with the formation of the oldest caldera of the island (La Vecchia) is dated at $140 \pm 2 \mathrm{ka} \mathrm{BP}$ (Rotolo et al., 2013; Scaillet et al., 2013). A voluminous ignimbrite was later erupted at $85 \mathrm{ka}$ before extensive ring-dyke eruptions occurred at $67 \mathrm{ka} \mathrm{BP}$; finally, much of the island was covered by the widespread Green Tuff ignimbrite at $45 \mathrm{ka}$ (Scaillet et al., 2013).

\section{A Discussion of Possible Mechanisms}

The ability for fluctuating ocean loads to modulate volcanic activity on coastal and island volcanoes has been recognised at various scales (e.g., McNutt and Beavan, 1987; McNutt, 1999; Kutterolf et al., 2103; Ramalho et al., 2013; Crowley et al., 2015) and through various possible mechanisms. At Pantelleria, Wallman et al. (1988) attributed the major ring-fracture eruptions during the stadial lowstand at $67 \mathrm{ka}$ to the abrupt eustatic drawdown, showing that the stress changes from a $130 \mathrm{~m}$ sea-level fall would generate the right magnitude of horizontal tensile stress above the magma chamber to promote dike propagation. In contrast, stress changes associated with interglacial rises in sea level appear sufficient to increase magma ascent and fault movement in island-arc volcanic settings (cf. Nakada and Yokose, 1992). Rapid onset external loading can be expected to outpace viscoelastic relaxation, thereby promoting the overpressuring of magma chambers (Jellinek et al., 2004). Rising seas, and the accompanying rises in groundwater, can induce greater magma-water interaction at shallow levels and encourage explosive eruptive activity, while coastal erosion and sudden changes of pore-pressure conditions within basal layers can favour large-scale edifice failure (Quidelleur et al., 2008).

The specific geodynamic setting of Mount Etna, where a volcanic edifice has grown atop a structurally complex basement, suggests that an additional mode of modulation would be exerted via the seaboard faults (Timpe), which appear to have acted as persistent early magma pathways. Eustatic changes in response to the glacial-interglacial cycles can impose a cyclic variation in the normal stress acting on faults
(Hetzel and Hampel, 2005; Hampel and Hetzel, 2006; Luttrell et al., 2007; Luttrell and Sandwell, 2010; Li and Hampel, 2012), According to Luttrell and Sandwell (2010), when ocean levels are high the activity of onshore faults is promoted and when ocean levels are low onshore fault activity is inhibited, with the opposite tendencies for offshore faults. Moreover, in extensional settings, ocean loading can be expected to induce a flexural response of the continental seaboard, imposing a compressional regime below the rolling hinge and an extensional domain ahead of it (Luttrell et al., 2007; Luttrell and Sandwell, 2010).

Applying this scheme to the Etnean context, marine transgression onto the continental shelf would shift the offshore compressive strain field landward, potentially causing the tensile feeder systems of the coastal Timpe faults to become gradually pinched closed and shut down as easy magma pathways. Rising sea levels would induce a westward rolling flexural hinge that would enhance the dilational stress field prevailing further onshore. It could be envisaged that as the preferential eruptive axes at the coast 'locked up', fresh eruptive pathways would be unlocked inland. The net effect of successive eustatic rise periods (highstands) would have been to preferentially exploit fracture systems to the west of previously active eruptive centres. The initial opening up of new magma routeways would likely have taken several millenia, hence the passage of magma to the surface ought to have - for a time - been curtailed, resulting in more prolonged magma ascent and increased crystal fractionation in shallow reservoirs. This is consistent with the significantly more evolved compositions (mugearite to benmoreite) erupted in the early stages of the Valle del Bove centres. The resulting intrusion of a large magmatic body - evident from seismic tomography studies beneath the edifice - is likely to have been the impetus for progressive bulging and then gravitational collapse of the eastern flank over the last $100 \mathrm{ka}$ (Branca et al., 2008; Argnani et al., 2013). That gravitational-sliding might also be mediated by sea-level change, thereby providing an additional mechanism to control shallow magma ascent and eruption (Chiocci et al., 2011). Under this shallow gravitational regime, collapse effects on the submarine continental margin propagate retrogressively upslope, promoting decompression at the volcano summit and favouring the ascent of basic magma without lengthy storage in the upper crust (Chiocci et al., 2011). In this way, decametre-scale eustatic changes could be expected to modulate coastal flank collapse, with sea-level falls promoting gravitational sliding and sea-level rises inhibiting it (cf. McGuire et al., 1997a). This supports the current view that volcano edifice and continental margin instability are coupled (Gross et al., 2016).

\section{Conclusions}

The association between eustatic change and the volcanic evolution of Mount Etna is inferred from an apparent close correspondence between the timing of major sea-level transitions and magmatic transitions. Refining that association and resolving precisely how eustatic change might orchestrate deeper-seated magmatic change will require a far more detailed picture of the late Pleistocene development of Mount Etna's continental margin and a higher resolution radiometric framework for the onshore edifice. Insights could come from theoretical modelling of the potential stress effects of ocean loading, but they are likely to remain ambiguous in the absence of a better understanding 
of the volcanic plumbing system. Nevertheless, the present scheme, although speculative, offers a hypothesis that can be robustly tested, postulating that late Pleistocene eustatic chronologies ought to define major volcanic reorganisations not only at Mount Etna but at other coastal and island volcanoes. It is possible that with improved radiometric control and a more complete volcano-tectonic understanding, the provocative contentions made here may be proved untenable. However, future studies on this topic must also provide a plausible explanation for the conundrum that remains at the heart of this paper: why did Mount Etna suddenly switch its eruptive character 130,000 years ago?

\section{Acknowledgements}

This manuscript benefitted greatly from discussions and comments on early drafts from Stuart Scott, Bill McGuire, Paul Cole, Anita di Chiara and Andrea Argnani, as well as from insightful reviews by Mike Cassidy, an anonymous referee and handling editor Elizabeth Rovere.

\section{References}

Argnani, A., and Bonazzi, C., 2005, Malta Escarpment fault zone offshore eastern Sicily: Pliocene-Quaternary tectonic evolution based on new multichannel seismic data. Tectonics, v. 24. DOI: 10.1029/2004TC001656

Argnani, A., Mazzarini, F., Bonazzi, C., Bisson, M., and Isola, I., 2013, The deformation offshore of Mount Etna as imaged by multichannel seismic reflection profiles. Journal of Volcanology and Geothermal Research, v. 251 , pp. 50-64.

Antonioli, F., S. Kershaw, S, Renda, P., Rust, D., Belluomini, G., Cerasoli, M., Radtke, U., and Silenzi, S., 2006, Elevation of the last interglacial highstand in Sicily (Italy): a benchmark of coastal tectonics. Quaternary Science Reviews, v. 145-146, pp. 3-18.

Azzaro, R., 1999, Earthquake surface faulting at Mount Etna volcano (Sicily) and implications for active tectonics. Journal of Geodynamics, v. 28, pp. 193-213.

Azzaro, R., Bonforte, A., Branca, S., and Guglielmino, F., 2013, Geometry and kinematics of the fault systems controlling the unstable flank of Etna volcano (Sicily). Journal of Volcanology and Geothermal Research, v. 251, pp. 5-15.

Branca, S., Coltelli, M., and Groppelli, G., 2004, Geological evolution of Etna volcano. In: Bonaccorso, A., Calvari, S., Coltelli, M., Del Negro, C., and Falsaperla, S. (Eds.), AGU Monograph Series, Mount Etna Volcano Laboratory, v. 143, pp. 49-63.

Branca, S., Coltelli, M., De Beni, E., and Wijbrans, J., 2007, Geological evolution of Mount Etna volcano (Italy) from earliest products until the first central volcanism (between 500 and $100 \mathrm{ka}$ ago) inferred from geochronological and stratigraphic data. International Journal of Earth Sciences, v. 97, pp. 135-152.

Carracedo, J.C., Day, S.J., Guillou, H., and Torrado, F.J.P., 1999, Giant Quaternary landslides in the evolution of La Palma and El Hierro, Canary Islands. Journal of Volcanology and Geothermal Research, v. 94, pp. 169-190.

Cassidy, M., Taylor, R.N., Palmer, M.R., Cooper, R.J., Stenlake, C., and Trofimovs, J., 2012, Tracking the magmatic evolution of island arc volcanism: Insights from a high-precision $\mathrm{Pb}$ isotope record of Montserrat, Lesser Antilles. Geochemistry, Geophysics, Geosystems, v. 13. DOI: $10.1029 / 2012 \mathrm{GC} 004064$

Cassidy, M., Watt, S.F.L., Talling, P.J., Palmer, M.R., Edmonds, M., Jut- zeler, M., Wall-Palmer, D., Manga, M., Coussens, M., Gernon, T., and Taylor, R.N., 2015, Rapid onset of mafic magmatism facilitated by volcanic edifice collapse. Geophysical Research Letters, v. 42, pp. 4778 4785.

Catalano, S., and De Guidi, G., 2003, Late Quaternary uplift of northeastern Sicily: relation with the active normal faulting deformation. Journal of Geodynamics, v. 36, pp. 445-467.

Catalano, S., Torrisi, S., and Ferlito, C., 2004, The relationship between Late Quaternary deformation and volcanism of Mt. Etna (eastern Sicily): new evidence from the sedimentary substratum in the Catania region. Journal of Volcanology and Geothermal Research, v. 132, pp. 311-334.

Chiocci, F.L., Coltelli, M., Bosman, A., and Cavallaro, D., 2011, Continental margin large-scale instability controlling the flank sliding of Etna volcano. Earth and Planetary Science Letters, v. 305, pp. 57-64.

Coltelli, M., Del Carlo, P., and Vezzoli, L., 2000, Stratigraphic constraints for explosive activity in the past $100 \mathrm{ka}$ at Etna Volcano, Italy. International Journal of Earth Sciences, v. 89, pp. 665-677.

Corsaro, R.A., Neri, M., and Pompilio, M., 2002, Paleo-environmental and volcano-tectonic evolution of the southeastern flank of Mt. Etna during the last $225 \mathrm{ka}$ inferred from the volcanic succession of the 'Timpe', Acireale, Sicily. Journal of Volcanology and Geothermal Research, v. 113, pp. 289-306.

Coussens, M., Wall-Palmer, D., Talling, P., Watt, S., Cassidy, M., Jutzeler, M., Clare, M.A., Hunt, J., Manga, M., Gernon, T., and Palmer, M., 2016, The relationship between eruptive activity, flank collapse, and sea level at volcanic islands: a long-term $(>1 \mathrm{Ma})$ record offshore Montserrat, Lesser Antilles. Geochemistry, Geophysics, Geosystems, v. 17, pp. 2591-2611.

Crowley, J.W., Katz, R.F., Huybers, P., Langmuir, C.H., and Park, S.H., 2015, Glacial cycles drive variations in the production of oceanic crust. Science, v. 347, pp. 1237-1240.

Cutler, K.B., Edwards, R.L., Taylor, F.W., Cheng, H., Adkins, J., Gallup, C.D., Cutler, P.M., Burr, G.S., and Bloom, A.L., 2003, Rapid sea-level fall and deep-ocean temperature change since the last interglacial period. Earth and Planetary Science Letters, v. 206, pp. 253-271.

De Astis, G., La Volpe, L., Peccerillo, A., and Civetta, L., 1997, Volcanological and petrological evolution of Vulcano island (Aeolian Arc, southern Tyrrhenian Sea). Journal of Geophysical Research, v. 102, pp. 8021-8050.

De Beni, E., and Groppelli, G., $2010,{ }^{40} \mathrm{Ar} /{ }^{39} \mathrm{Ar}$ radiometric dating to constrain the volcanic stratigraphy: The Mt. Etna methodological case. In: Groppelli, G., and Viereck-Goette, L. (Eds.), Stratigraphy and Geology of Volcanic Areas. Geological Society of America, Special Paper, v. 464, pp. 241-248.

De Beni, E., Wijbrans, J.R., Branca, S., Coltelli, M., and Groppelli, G., 2005, New results of ${ }^{40} \mathrm{Ar}{ }^{\beta 9} \mathrm{Ar}$ dating constrain the timing of transition from fissure-type to central volcanism at Mount Etna (Italy). Terra Nova, v. 17, pp. 292-298.

De Beni, E., Branca, S., Coltelli, M., Groppelli, G., and Wijbrans, J.R., $2011,{ }^{40} \mathrm{Ar}{ }^{\beta 9} \mathrm{Ar}$ isotopic dating of Etna volcanic succession. Italian Journal of Geosciences, v. 130, pp. 292-305.

De Rosa, R., Guillou, H., Mazzuoli, R., and Ventura, G., 2003, New unspiked $\mathrm{K} / \mathrm{Ar}$ ages of volcanic rocks of the central and western sector of the Aeolian Islands: reconstruction of the volcanic stages. Journal of Volcanology and Geothermal Research, v. 120, pp. 161-178.

De Guidi, G., Catalano, S., Monaco, C., and Tortorici, L., 2003, Morphological evidence of Holocene coseismic deformation in the Taormina region (NE Sicily). Journal of Geodynamics, v. 36, pp. 193-211.

Del Carlo, P., Vezzoli, L., and Coltelli, M., 2004, Last 100 ka tephrostratigraphic record of Mount Etna. In: Calvari, S., Bonaccorso, A., Coltelli, M., Del Negro, C., and Falsaperla, S. (Eds.), AGU Monograph Series, Etna Volcano Laboratory, v. 143, pp. 77-89.

Doglioni, C., Innocenti, F., and Mariotti, G., 2001, Why Mount Etna? Terra Nova, v. 13, pp. 25-31.

Francalanci, L., Lucchi, F., Keller, J., De Astis, G., and Tranne, C.A., 2013, 
Eruptive, volcano-tectonic and magmatic history of the Stromboli volcano (north-eastern Aeolian archipelago). Geological Society of London, Memoirs, v. 37, pp. 397-471.

Gallup, C.D., Cheng, H., Taylor, F.W., and Edwards, R.L., 2002, Direct determination of the timing of sea-level change during termination II. Science, v. 295, pp. 310-313.

Germa, A., Quidelleur, X., Lahitte, P., Labanieh, S., and Chauvel, C., 2011, The K-Ar Cassignol-Gillot technique applied to western Martinique lavas: a record of Lesser Antilles arc activity from 2 Ma to Mount Pelée volcanism. Quaternary Geochronology, v. 6, pp. 341-355.

Gillot, P.Y., Keiffer, G., and Romano, R., 1994, The evolution of Mount Etna in the light of potassium-argon dating. Acta Volcanologia, v. 5, pp. 81-87.

Gross, F., Krastel, S., Geersen, J., Behrmann, J.H., Ridente, D., Chiocci, F.L., Bialas, J., Papenberg, C., Cukur, D., Urlaub, M., and Micallef, A., 2016, The limits of seaward spreading and slope instability at the continental margin offshore Mt Etna, imaged by high-resolution 2D seismic data. Tectonophysics, v. 667, pp. 63-76.

Guillou, P.-Y., Carracedo, J.C., and Day, S.J., 1998, Dating of the Upper Pleistocene-Holocene volcanic activity of La Palma using the unspiked K-Ar technique. Journal of Volcanology and Geothermal Research, v. 86, pp. 137-149.

Hampel, A., and Hetzel, R., 2006, Response of normal faults to glacialinterglacial fluctuations of ice and water masses on Earth's surface. Journal of Geophysical Research, v. 111, pp. B06406.

Hetzel, R., and Hampel, A., 2005, Slip rate variations on normal faults during glacial-interglacial changes in surface loads. Nature, v. 435, pp. 81-84.

Hirn, A., Nicolich, R., Gallart, J., Laigle, M., Cernobori, L., and ETNASEIS Scientific Group, 1997, Roots of Etna volcano in faults of great earthquakes. Earth and Planetary Science Letters, v. 148, pp. 171-191.

Hunt, J.E., Wynn, R.B., Talling, P.J., and Masson, D.G., 2013, Turbidite record of frequency and source of large volume $\left(>100 \mathrm{~km}^{3}\right)$ Canary Island landslides in the last 1.5 Ma: implications for landslide triggers and geohazards. Geochemistry, Geophysics, Geosystems, v. 14, pp. 2100-2123.

Imbrie, J., Hays, J.D., Martinson, D.G., Mcintyre, A., Mix, A.C., Morley, J.J., Pisias, N.G., Prell, W.L., and Shackleton, N.J., 1984, The orbital theory of Pleistocene climate: support from a revised chronology of the marine record. In: Berger, A.L., Imbrie, J., Hays, J., Kukla, G., and Saltzman, B. (Eds.), Milankovitch and Climate, Part 1. Reidel Publishing Company, Dordrecht, pp. 269-305.

Jellinek, A.M., Manga, M., and Saar, M.O., 2004, Did melting glaciers cause volcanic eruptions in eastern California? Probing the mechanics of dike formation. Journal of Geophysical Research: Solid Earth, v. 109. DOI: $10.1029 / 2004 J B 002978$

Kopp, R.E., Simons, F.J., Mitrovica, J.X., Maloof, A.C., and Oppenheimer, M., 2009, Probabilistic assessment of sea level during the last interglacial stage. Nature, v. 462, pp. 863-867.

Kutterolf, S., Jegen, M., Mitrovica, J.X., Kwasnitschka, T., Freundt, A., and Huybers, P.J., 2013, A detection of Milankovitch frequencies in global volcanic activity. Geology, v. 41, pp. 227-230.

Lambeck, K., Esat, T.M., and Potter, E-K., 2002, Links between climate and sea levels for the past three million years. Nature, v. 419, pp. 199206.

Lanzo, G., Basile, S., Brai, M., and Rizzo, S., 2010, Volcanic products of Lipari (Aeolian islands, Italy): multivariate analysis of petrographic and radiometric data. Radiation Measurements, v. 45, pp. 816-822.

Léocat, E., 2010, Histoire éruptive des volcans du secteur occidental des Iles Eoliennes (Sud de la Mer Tyrrhénienne, Italie) et évolution temporelle du magmatisme. Doctoral Dissertation, Université de Paris-Sud, Orsay.

Li, T., and Hampel, A., 2012, Effect of glacial-interglacial sea-level changes on the displacement and stress field in the forearc and along the plate interface of subduction zones. Solid Earth, v. 3, pp. 63.
Lo Giudice, E., and Rasa, R., 1986, The role of the NNW-structural trend in the recent geodynamic evolution of north-east Sicily and its volcanic implications in the Etnean area. Journal of Geodynamics, v. 5, pp. 309-330.

Lucchi, F., 2013, Stratigraphic methodology for the geological mapping of volcanic areas: insights from the Aeolian archipelago (southern Italy). Geological Society of London, Memoirs, v. 37, pp. 37-53.

Lucchi, F., Peccerillo, A., Keller, J., Tranne, C.A., and Rossi, P.L. (Eds.), 2013a, The Aeolian Islands Volcanoes. Geological Society of London, Memoir, v. 37, 520 p.

Luttrell, K., and Sandwell, D., 2010, Ocean loading effects on stress at near shore plate boundary fault systems. Journal of Geophysical Research, v. 115, pp. B08411.

Luttrell, K., Sandwell, D., Smith-Konter, B., Bills, B., and Bock, Y., 2007, Modulation of the earthquake cycle at the southern San Andreas fault by lake loading. Journal of Geophysical Research, v. 112, pp. B08411.

McGuire, W., 1996, Volcano instability: a review of contemporary themes. Geological Society of London, Special Publication, v. 110, pp. 1-23.

McGuire, W.J., Stewart, I.S., and Saunders, S.J., 1997a, Intra-volcanic rifting at Mount Etna in the context of regional tectonics. Acta Vulcanologica, v. 9, pp. 163-172.

McGuire, W.J., Howarth, R.J., Firth, C.R., Solow, A.R., Pullen, A.D., Saunders, S.J., Stewart, I.S., and Vita-Finzi, C., 1997b, Correlation between rate of sea-level change and frequency of explosive volcanism in the Mediterranean. Nature, v. 389, pp. 473-476.

Mahood, G.A., and Hildreth, W., 1986, Geology of the peralkaline volcano at Pantelleria, Strait of Sicily. Bulletin of Volcanology, v. 48, pp. 143 172.

Monaco, C., 1997, Tettonica Pleistocenica nell'area a sud dell'Etna (Sicilia Orientale). Il Quaternario, v. 10, pp. 395-400.

Monaco, C., Tapponier, P., Tortorici, L., and Gillot, P.Y., 1997, Late Quaternary slip rate on the Acireale-Piedmonte normal faults and tectonic origin of Mount Etna (Sicily). Earth and Planetary Science Letters, v. 147, pp. 125-139.

Monaco, C., Bianca, M., Catalano, S., De Guidi, G., and Tortorici, L., 2002, Sudden change in the Late Quaternary tectonic regime in eastern Sicily: evidences from geological and geomorphological features. Italian Journal of Geosciences, v. 1, pp. 901-913.

Manconi, A., Longpré, M.A., Walter, T.R., Troll, V.R., and Hansteen, T.H., 2009, The effects of flank collapses on volcano plumbing systems. Geology, v. 37, pp. 1099-1102.

McMurtry, G.M., Herrero-Bervera, E., Cremer, M.D., Smith, J.R., Resig, J., Sherman, C., and Torresan, M.E., 1999, Stratigraphic constraints on the timing and emplacement of the Alika 2 giant Hawaiian submarine landslide. Journal of Volcanology and Geothermal Research, v. 94, pp. 35-58.

McNutt, S.R., 1999, Eruptions of Pavlof Volcano, Alaska, and their possible modulation by ocean load and tectonic stresses: re-evaluation of the hypothesis based on new data from 1984-1998. Pure and Applied Geophysics, v. 155, pp. 701-712.

McNutt, S.R., and Beavan, R.J., 1987, Eruptions of Pavlof volcano and their possible modulation by ocean load and tectonic stress. Journal of Geophysical Research, v. 92, pp. 11,509-11,523.

Nakada, M., and Yokose, H., 1992, Ice age as a trigger of active Quaternary volcanism and tectonism. Tectonophysics, v. 212, pp. 321-329.

Nicolich, R., Laigle, M., Hirn, A., Cernobori, L., and Gallart, J., 2000, Crustal structure of the Ionian margin of Sicily: Etna volcano in the frame of regional evolution. Tectonophysics, v. 329, pp. 121-139.

Nicotra, E., Viccaro, M., De Rosa, R., and Sapienza, M., 2014, Volcanological evolution of the Rivi-Capo Volcanic Complex at Salina, Aeolian Islands: magma storage processes and ascent dynamics. Bulletin of Volcanology, v. 76, pp. 840.

Polonia, A., Torelli, L., Artoni, A., Carlini, M., Faccenna, C., Ferranti, L., Gasperini, L., Govers, R., Klaeschen, D., Monaco, C., and Neri, G., 2016, The Ionian and Alfeo-Etna fault zones: new segments of an 
evolving plate boundary in the central Mediterranean Sea? Tectonophysics, v. 675, pp. 69-90.

Potter, E.K., Esat, T.M., Schellmann, G., Radtke, U., Lambeck, K., and McCulloch, M.T., 2004, Suborbital-period sea-level oscillations during marine isotope substages $5 \mathrm{a}$ and $5 \mathrm{c}$. Earth and Planetary Science Letters, v. 225, pp. 191- 204.

Quidelleur, X., Hildenbrand, A., and Samper, A., 2008, Causal link between Quaternary paleoclimatic changes and volcanic islands evolution. Geophysical Research Letters, v. 35, pp. L02303.

Ramalho, R.S., Quartau, R., Trenhaile, A.S., Mitchell, N.C., Woodroffe, C.D., and Ávila, S.P., 2013, Coastal evolution on volcanic oceanic islands: a complex interplay between volcanism, erosion, sedimentation, sea-level change and biogenic production. Earth-Science Reviews, v. 127 , pp. $140-170$.

Rittman, A., 1973, Structure and evolution of Mount Etna. Philosophical Transactions of the Royal Society of London, Series A, v. 274, pp. 5-16.

Rohling, E.J., Grant, K., Hemlebem, C.H., Siddall, M., Hoogakker, B.A.A., Balshaw, M., and Kucera, M., 2008, High rates of sea-level rise during the last interglacial period. Nature Geoscience, v. 1, pp. 38-42.

Rotolo, S.G., Scaillet, S., La Felice, S., and Vita-Scaillet, G., 2013, A revision of the structure and stratigraphy of pre-Green Tuff ignimbrites at Pantelleria (Strait of Sicily). Journal of Volcanology and Geothermal Research, v. 250, pp. 61-74.

Ruch, J., Vezzoli, L., De Rosa, R., Di Lorenzo, R., and Acocella, V., 2016, Magmatic control along a strike-slip volcanic arc: the central Aeolian arc (Italy). Tectonics, v. 35, pp. 407-424.

Scaillet, S., Vita-Scaillet, G., and Rotolo, S.G., 2013, Millennial-scale phase relationships between ice-core and Mediterranean marine records: insights from high-precision ${ }^{40} \mathrm{Ar} /{ }^{39} \mathrm{Ar}$ dating of the Green Tuff of Pantelleria, Sicily Strait. Quaternary Science Reviews, v. 78, pp. 141-154.

Siddall, M., Rohling, E., Almogi-Labin, A., Hemleben, C., Meischner, D., Schmelzer, I., and Smeed, D.A., 2003, Sea-level fluctuations during the last glacial cycle. Nature, v. 423, pp. 853-858.

Spratt, R.M., and Lisiecki, L.E., 2016, A Late Pleistocene sea level stack. Climate of the Past, v. 12, pp. 1079.

Stirling, C.H., Esat, T.M., Lambeck, K., and McCulloch, M.T., 1998, Timing and duration of the Last Interglacial: evidence for a restricted inter- val of widespread coral reef growth. Earth and Planetary Science Letters, v. 160, pp. 745-762.

Thomas, A.L., Henderson, G.M. Deschamps, P., Yokoyama, Y., Mason, A.J., Bard, E., Hamelin, B., Durand, N., and Camoin, G., 2009, Penultimate deglacial sea-level timing from uranium/thorium dating of Tahitian corals. Science, v. 324, pp. 1186-1190.

Thompson, W.G., and Goldstein, S., 2005, Open-system coral ages reveal persistent suborbital sea-level cycles. Science, v. 308, pp. 401-404.

Tamburrino, S., Insinga, D.D., Sprovieri M., Petrosino, P., and Tiepolo, M., 2012, Major and trace element characterization of tephra layers offshore Pantelleria Island: insights into the last $200 \mathrm{ka}$ of volcanic activity and contribution to the Mediterranean tephrochronology. Journal of Quaternary Science, v. 27, pp. 129-140.

Wallman, P.C., Mahood, G.A., and Pollard, D.D., 1988, Mechanical models for correlation of ring-fracture eruptions at Pantelleria, Straits of Sicily, with glacial sea-level drawdown. Bulletin of Volcanology, v. 50, pp. 327-339.

Wall-Palmer, D., Coussens, M., Talling, P.J., Jutzeler, M., Cassidy, M., Marchant, I., Palmer, M.R., Watt, S.F., Smart, C.W., Fisher, J.K., and Hart, M.B., 2014, Late Pleistocene stratigraphy of IODP Site U1396 and compiled chronology offshore of south and south west Montserrat, Lesser Antilles. Geochemistry, Geophysics, Geosystems, v. 15, pp. 3000-3020.

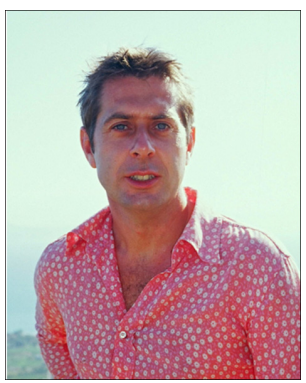

Iain Stewart is professor of Geoscience Communication at the University of Plymouth and Director of its Sustainable Earth Institute. He studied Geography and Geology at Strathclyde University, completed a PhD in earthquake geology at Bristol University and lectured in Earth Science at Brunel University until 2002, after which he joined Plymouth. His research interests are in interdisciplinary investigations of geological hazards and in the communication of geoscience to the public. He currently holds a UNESCO Chair in Geoscience and Society. 